\title{
GEOPOLITICS AT THE EASTERN BORDERS OF THE EUROPEAN UNION : EASTERN EUROPE BETWEEN THE EU AND RUSSIA 1
}

\author{
Dacian D una \\ Babes-Bolyai University \\ Cluj-Napoca/Romania \\ dunadacian@yahoo.com
}

\begin{abstract}
Geopolitics has changed dramatically over the last century, from a modernist discipline focused on the impact of geography on politics and international relations, to a postmodern approach in which traditional assumptions of reality are getting blurred, like the in-out distinction, borders are getting permeable, and state-centrism is replaced by multiplicity. A postmodern actor such as the European Union provides a good example of the sort. The EU has managed to assimilate most of the instruments and policies developed during the course of European integration, including regional policy, or cross-border cooperation, a territorial approach to development across the border regions of Europe pioneered by the Council of Europe since the 1950s. This paper tries to compare the policies of the European Union pre- and post-enlargement regarding Eastern Europe, using a geopolitical approach, questioning whether the recent
\end{abstract}

${ }^{1}$ The present paper is published under the framework of Jean Monnet Centre of Excelence "In and Out: Understanding the European Union Beyond Its Borders", nr. 565330-EPP-1-2015-1-RO-EPPJM O-COE 
geopolitical resurgence of Russia has the potential to question the influence of the European Union over its Eastern neighbourhood.

\section{Keywords}

Enlargement, fragmentation, neighbourhood, geopolitics, EU, Eastern Europe, CBC, integration,

\section{INTRODUCTION}

Globalization is undisputedly one of the processes that shape the present of our planet. It is the logical development of a large sum of events, patterns and trends that took place since the times of the industrial revolution. The victory of the Western model of society - a model based on political and economic liberalism - over its totalitarian rivals once promised a peaceful global order that would last forever. Many political thinkers and practitioners anticipated the end of geopolitics, not only the end of history. They referred to that kind of geopolitics that divided the world into camps as becoming obsolete. However, have the last years witnessed the "revenge of geography" as Robert Kaplan argued (Kaplan 2012), or maybe the revenge of geo-strategy, that sub-field of geopolitics studied by the infamous school of geopolitics of general Haushofer? Is this what is happening in Eastern Europe, especially in the areas that remained outside the enlargements of the Western institutions? Or in fact geopolitics was never abandoned? These are some of the questions that still need answers. Unfortunately, the honeymoon between ,East' and ,West' seems now long gone and the events that took place not long ago in Georgia or Ukraine are potentially hazardous for the whole of Europe. The policies of the Western organizations have not been able to prevent them.

Looking back to the last decades one could hardly miss that geopolitics as discipline and practice has returned, though fundamentally changed. It was an epistemological change. Geopolitics came back to the centre of analysing the global space with the help of critical geopolitics. However, as the promise of neoliberalism with its focus on geo-economics failed to materialize, classical geopolitics returned as well. 
Classical geopolitics "rests upon the relative spatial positions of countries, regions, and resources as these may affect their foreign policies and actions. Such terms as states' and regions' locations, topography, distance, shape, and size will accompany these geographic features. And within these spatial structures, we may see certain patterns as depicted in shatterbelts, buffers, heartlands, sea power and land power, and checkerboards, among the numerous concepts-theories attached to the study of geopolitics" (Kelly 2016, 2). Another definition, provided by Saul B. Cohen, is even more instrumental for our analysis. According to Cohen, geopolitics is "the analysis of the interaction between, on the one hand, geographical settings and perspectives and, on the other, political processes. The settings are composed of geographical features and patterns and the multilayered regions that they form. The political processes include forces that operate at the international level and those on the domestic scene that influence international behaviour" (Cohen 2015, 16). Clearly, the focus of this paper falls on the linkage between the European integration process and the multi-layered geopolitical realities of Eastern Europe.

On the other hand, critical geopolitics deconstructed the modernist assumptions and meanings used in the theory and practice of geopolitics and statecraft. According to Toal, critical geopolitics has taken up the challenge "to document and deconstruct the institutional, technological, and material forms of these new congealments of geo-power, to problematize how global space is incessantly reimagined and rewritten by centers of power and authority in the late twentieth century" (Toal 1996, 196). Critical geopolitics is a new representation of "geopolitics as a discourse comprising two overlapping components. First, the 'practical geopolitics' of everyday statescraft, whereby the world is spatialized into regions with imagined attributes and characteristics-leading to a mosaic of places of 'danger', 'threat', or 'safety' that underpins foreign policy. Second, the 'formal geopolitics' created by 'security intellectuals' who produced theories and strategies to guide and justify the statecraft of practical geopolitics" (Ó Tuathail and Agnew 1992 in Dodds, Atkinson 2000, 10). Critical or postmodern geopolitics seem to better describe the geopolitical features of a postmodern actor such as the European Union.

Eastern Europe has always been an object of dispute between the empires of Western Eurasia. The appearance of emancipation felt after the Cold War inside the region has soon proved to be an illusion. The region is still parcelled between the interests of the Western organizations and those of the Russian Federation. It remained caught between two discourses with geopolitical implications. On the one hand, the 
discourse of a metaphorical empire, as Ole Waever would argue, based on liberalism, conditionality and differentiation, the European Union. On the other hand, the discourse of an old empire, championing the old ways, the conservative values, against the so-called Western decadence, the Russian Federation. The dilemma remains largely economic, since the most important problem of Eastern Europe is its constant dependence on energy, technology, and investments due to its historical poorness. For the most part of the period (1990-2010) the East European nations had mostly depended on the EU, but since the European economic crisis the credibility of the European Union did show signs of fluctuations. Austerity dramatically changed the behaviour of the European institutions not only in what concerns fiscal discipline within the Member States of the EU but also in terms of its external relations. The EU is far less generous with its current Eastern neighbours than it used to be in the 1990s with the countries of Central Europe.

This paper is approaching the policies of the European institutions, particularly those of the European Community and the European Union with regard to Eastern Europe after the fall of communism and the breakup of the Soviet Union using geopolitical lenses.

\section{DIFFERENTIATION AND CONDITIONALITY}

Since the early 1990s the European Union has had to define its relations with the neighbouring areas in a wide spectrum of issues and using a complex mixture of policies. Among them were the CFSP-CSDP, the regional policy, the cross-border cooperation policy, JHA and so. The EU was not alone in this matter. It was accompanied and still is by a plethora of IGOs, INGOs, corporations, or firms. The most important companions added consistence to the Western approach of Eastern Europe: The North Atlantic Alliance (NATO), the Council of Europe, or OSCE, covering all the aspects necessary for strengthening the East-West rapprochement after the long decades of the Cold War. This evolution was actually the Western feedback following the input received from the ,East'. A number of Central European countries, namely Poland, Czechoslovakia (before the split), and Hungary had noticed the openness of the Western institutions soon after the fall of communism, 
cooperating together to join the Euro-Atlantic institutions while at the same time preparing their societies for political liberalism and market economy.

In this atmosphere it seemed the West was once again embracing the East. However, the process was not a smooth one. It soon became clear that Eastern Europe has not been a monolith after all during the times of the Cold War. The monolith was cracked and the demise of communism made it implode. The Western institutions came soon to realize that Eastern Europe was regionally diversified and a process of differentiation was soon employed in the relations with the East. According to Peter Gowan (Gowan 2002, 29-30) the Eastern Europe was split into several sub-areas from Europe's point of view:

- The Frontier Belt formed by states neighbouring directly Germany and/or Austria: Poland, Czech Republic, Slovakia, Hungary, and Slovenia. Croatia's involvement in the Western Balkans' wars gave it for a moment an economic, political, and strategic profile different from other frontier belt states;

- South-Eastern Europe and the Western Balkans: this area includes Romania and Bulgaria, Albania, and all the successor countries of Yugoslavia, except Slovenia;

- The Baltic region: the Baltic states and Kaliningrad;

- The Western part of the CIS: Russia, Ukraine, Belarus, and Moldova;

- The Caucasus: especially Armenia, Georgia, and Azerbaijan.

The regional differentiation noticed by Gowan may have been once a reality from the point of view of European and Atlantic institutions. Obviously, the reality changed dramatically, once Romania, Bulgaria, Croatia, and Albania joined the European Union and/or NATO. What is important is the fact that the regional differentiation operated by the European institutions probably covered some geopolitical considerations along the classical economic or political ones (specific to a civilian power such as the EU). This policy of regional differentiation reflects the gradual extension of European Union's interest towards its Eastern European neighbours after the end of communism in Eastern Europe. This interest was getting compartmentalized depending on regional circumstances. Not surprisingly, the main target for the EU enlargement policy was initially the Central European sub-region, mainly because its countries had rapidly succeeded in cooperating in a joint manner with a view to their admission to the European and Atlantic organizations (using 
such initiatives as the Visegrad Group, CEFTA, or the Central European Initiative). Yet, probably the most important argument was the fact that this frontier belt' countries could have formed the first line of defence in the wake of the new crossborder security threats foreshadowing the Eastern border of the Union in the early 1990s.

After the fall of Berlin Wall some voices had suggested a new historical and "natural" divide (as Milan Kundera argued) between East and West, or a new wall separating the "Cosmos" from "Chaos". Especially the Northern countries hurried to create regional cooperation initiatives in the Baltic and Barents seas beyond the new "big cultural division." The regional institutions were regarded as instruments to approach the problems of the chaotic "Other", but also "meeting points" of "interface" between different political cultures and old enemies (Tunander, 1997, 27). Immediately after the Cold War there was a temptation from the West to divide Europe - this time into three parts: the West, a restricted Central Europe that was expected to share the Western political culture (the Visegrad Group), and a new Eastern Europe (described as chaotic, unstable, based on the Eastern political culture). Gradually the European institutions have realized that they were the only entities able to order the "Chaos" of the neighbouring regions. The enlargement served this goal. Moreover, the narrowed sense of Central Europe was gradually abandoned as the European and Atlantic institutions have found the necessity to strengthen the new fragile democracies of Central and Eastern Europe in order to isolate the areas of risk for the European security.

Ola Tunander, a former researcher of the Peace Research Institute Oslo (PRIO), anticipated the new geopolitical division lines of the post-Cold War era: 1) NATO $\leftrightarrow$ Russia - focus on Germany, Northern Europe and Central Europe; 2) Europe $\leftrightarrow$ Islam - focus on Latin Southern Europe; 3) Limes Romanus $\leftrightarrow$ Limes Germanicus ${ }^{1}$ caused by the accent on either the North or the South of Europe, resulting in tensions within the EU (Tunander 1997, 24). The European political establishment categorically refused to formulate such dilemmas in geopolitical terms (politically

${ }^{1}$ During the Roman Empire, limes (spelled in English /'las mis/) was the frontier separating the Roman world from the Northern barbarian world ('Barbaricum'). 
incorrect). However, a close-up inspection of the regional policies developed by the European and Atlantic organizations in the last decades provides the evidence of an approach as the one remarked by Tunander. After the Cold War there was a period during which high-security or geostrategic concerns were no longer present. Instead, the type of threats to security has significantly changed, the concerns over microsecurity, or low security, have generously occupied the agenda. The states beyond the borders of Europe were no longer the most acute danger for the Western European security. The main danger came from the criminal activities developed within their borders with an important transnational impact.

Given that European integration also implied the adoption of the Schengen acquis, it is understandable that the enlargement of the EU has awakened many anxieties in the West. The two major concerns of the EU have become cross-border migration and crime (the latter covering a large number of issues including smuggling, human trafficking, drugs, terrorism, etc.), border control being considered by the Union as the main line of defence against instability and its consequences: refugees, murder and the collapse of law and order (Grabbe 2000). Although not all of these anxieties were not properly associated with the opening of borders to EU candidate countries, they have not lost their importance. Not by accident, the securing of borders with non-member states has become a priority for candidates' accession negotiations, and cross-border cooperation has become a major component of the relations between the EU and its neighbours.

The institutionalization of Nordic / Baltic security was also a reaction to the tragic experience of the Western Balkans. The Nordic people have shown their lack of interest in what was going on in southern Europe. After the fall of communism, NATO, WEU and CE / EU relations with the East were based on a semantic policy aimed at reducing Russia's fears. These institutions have avoided the use of the word "expansion" - a term far too offensive for Russia - replacing it with "opening" and then "enlarging". The three organizations based their enlargement policies on a rational strategy that would allow for the internal cohesion of the European institutions and their operational capacity to be maintained and ensure that there are no serious complaints from stronger neighbours (such as the Russian Federation) which could undermine the development of a European cooperative security system (Grudzinski, Ham 1999). 
Since the early 1990s, the European Community (EC) has differentiated the countries eligible for future European integration from those that are not eligible in the medium and even long term to join the European institutions. Of the former Soviet republics, only the Baltic states have been included in the first category. The aforementioned considerations have made Russia and the CIS member states (perceived as gravitating around Moscow) not to be considered eligible. Central European and Southeast European states (much later, following the adoption of the Stability Pact for Southeast Europe) have thus become the target of the enlargement policy of the European Community. Paradoxically, the Federal Republic of Yugoslavia could have been at the forefront of the list, given its relative openness towards the West since the 1970s. According to Peter Gowan, four factors, however, led to the final division, which enshrines the primacy of the Central European states in front of the Southeast European countries in the process of enlargement of the European Union: the clash between the local political tragedies and the Western shock therapy campaign launched in 1989; the impact of the German geopolitical priorities on both regions; the impact of the Yugoslav wars; the Albanian crisis (Gowan 2002, 30).

The perception of regional membership of potential candidate countries in the Union was dictated by geopolitical criteria, "Central Europe" symbolizing stability and security in Western mentality, while South Eastern Europe (especially the Western Balkans) being perceived as a source of insecurity, violence and the lack of a Western-style political culture. Over time, this difference in perception will turn as the ethnic, political and economic situation in Southeast Europe stabilizes. After the European economic intervention in Bulgaria (after the hyperinflation in 1997) and especially after the successful implementation of the Stability and Conflict Prevention FYROM pact, it became clear that the region of South-eastern Europe can also be secured and could join in the future the European and Atlantic organizations.

As the European Union matured as an international actor, developing a European (Common) Security and Defence Policy, it became clear to EU officials that the borders of European security transcend the European continent, especially in the context of the new wave of enlargement, considered rightly by political analysts as a true "enlargement boom" or "Big Bang". In this context, the EU was becoming more and more responsible for what is happening in the neighbourhood of wider Europe. 
It should be noted that if the regional policy of the European Union was marked for more than a decade by the enlargement to the East, this policy has reached its geographical and functional limits in the early 2000s. For the European Union the challenge was already identified in 2003: "H ow to exert an influence comparable to that exerted over the past decade on central and eastern Europe, but without being able to use the strict conditions for a possible accession?" (Batt, Lynch 2003 7).

The European institutions' response did not lack creativity. In fact, the year 2003 was extremely fruitful in terms of policy initiatives. It was revolutionary compared to most years of the European integration process ${ }^{1}$. Two particular documents are important in the context of this paper: "A Secure Europe in a Better World", the document presented by Javier Solana which later was adopted as the EU security strategy (EUSS), and a communication paper of the European Commission entitled "Europe's Wider Neighbourhood", which lead to the adoption of the European Neighbourhood Policy. Both were submitted to the European Council of Thesaloniki in June 2003. The documents confirmed once again the Western concerns over the Eastern European countries. The Solana document even used the findings from a Eurobarometer (No. 58/1 of Oct./Nov. 2002) to stress how the European institutions were caring about the perceptions of the European public.

The EUSS was adopted in December 2003. For a text imbued with neoliberal principles specific to the European integration process, the Solana document is filled with geopolitical reasoning. It clearly states that „our task is to promote a ring of well governed countries to the East of the European Union and on the borders of the Mediterranean with whom we can enjoy close and cooperative relations (...) It is not in our interest that enlargement should create new dividing lines in Europe. We need to extend the benefits of economic and political cooperation to our neighbours in the East while tackling political problems there" (EUSS 2003, 8). The tone is vaguely imperial, reminding about a theory developed by Robert Cooper, a very influential

${ }^{1}$ In 2003 the Convention on the Future of Europe finished the draft Treaty establishing a Constitution for Europe, the European Community presented a paper on "Wider Europe's Neighbourhood" which was the blueprint of the European Neighbourhood Policy established in 2004, and Javier Solana presented the EU's security strategy "A Secure Europe in a Better World". 
British diplomat of the Blair administration. The theory, "new liberal imperialism" was very fashionable during the years following 9/11. The strategy is over-optimistic in what concerns the ability of the European Union to model its Eastern and Southern neighbourhood into its own image.

Another surprising document is "Wider Europe's Neighbourhood: proposed new framework for relations with the EU's Eastern and Southern Neighbours" and it was drafted under the supervision of Chris Patten, another British diplomat, at that time European Commissioner for External Relations. It targeted the countries soon to become the new Eastern and Southern neighbours of the EU. The strategy concerns relations with Russia, the new independent states in the western part of the former USSR - Ukraine, Belarus, Moldova, and the South-Mediterranean countries. It agrees with the conclusions of the Copenhagen European Council (December 2002) that the enlargement is an opportunity to promote stability and prosperity beyond the borders of the Union. The document is similar in many respects to the EUSS: "Instead of trying to establish new dividing lines, deeper integration between the EU and the ring of friends will accelerate our mutual political, economic and cultural dynamism". It proposed a strategy for the next decade, starting from Chris Patten's findings: "O ver the past decade, the U nion's most successful foreign policy instrument has undeniably been the promise of EU membership. This is not sustainable. For the coming decade, we need to find new ways to export the stability, security and prosperity we have created within the enlarged EU. W e should begin by agreeing on a clearer vision for relations with our neighbours." (European Commission, 11 March 2003).

The Commission communication spoke of the development of a zone of prosperity and good neighbourliness, a "circle of friends" holding "a stake in the Internal Market" in return for demonstrating commitment to common EU values and effective implementation of reforms (political and economic). Romano Prodi, at that time President of the European Commission, expressed himself in a similar way to the one in the Solana document: "Instead of trying to establish new divisive lines, the strong integration between the EU and its circle of friends will accelerate our political dynamism, economic and cultural". Undoubtedly, the ideas suggested in the Commission's Communication and empirically grounded in the European Neighbourhood Policy are part of a new geopolitical vision of the European Union, of a new approach to regional security. 
One of the most interesting concepts developed in the years preceding the enlargement boom of the European Union was formulated by a theorist of neomedievalism: Ole Wæver. According to Wæver, the enlarged Europe has the potential to become a "a metaphorical empire", which leads us to think about multiplicity, overlapping authorities, the existence of multiple power centres. According to Wæver, the functions of this geopolitical organization would be to keep the core "intact" (this was the function of NATO's expansion waves for example), "to discipline" the regions in the proximity of the centre by using an asymmetric interdependence formula (see the conditionality for enlargement), direct intervention (an option which was supposed to become available with the emergence of the CSDP) (Wæver 1997).

Wæver approached both the European Union's and Russia's policies toward East Europe as being based on concentric circles. According to the author this is a system "that demands a lot of the EU system because ultimately it can only function if the perspective of eventual membership is kept realistic" (Wæver 1997, 336). Indeed, the EU policies toward the neighbourhood seem to justify exactly this approach specific to an empire. However, this could only have lead to a clash with Russia, the other empire using concentric circles of imperial control.

The problem with the European Union is that it was always suppose to be an entity that promotes openness and democracy. The "treaties" have always been drafted in a liberal manner, never suggesting that the EU might become a closed political system, a club of the rich. However, the enlargement "big bang" and the economic crises, followed by austerity measures, made almost impossible for the European Union to keep indefinitely the promise of enlargement for the neighbourhood countries. Yet, the promise of "a stake in the Internal Market" in exchange of political change has kept the "European dream" alive for the citizens of these countries and some members of their elite. This partly explains what happened in Ukraine since 2004 and the "A rab Spring". The EU is a victim of its own previous successes. 


\section{FROM THE ENP TO THE EASTERN PARTNERSHIP}

The European Neighbourhood Policy was established in 2004, was reviewed in 2011 due to the consequences of the Arab Spring for the Southern partners of the EU and revised again in November 2015. The policy is stated to be in line with the Global Security Strategy for the European Union's Foreign and Security Policy presented by the High Representative of the EU for Foreign Affairs and Security Policy, Federica Mogherini, in 2016. The policy is considered a "joint endeavour" between the EU represented by the European External Action Service and the EU Member States, on one side, and the 16 partner countries from Northern Africa, the Middle East and Eastern Europe.

A single look at the website of the European Neighbourhood Policy is enough to notice that the revised ENP is an instrument of the same policy of differentiation designed by the European Community and its successor, the EU, for the past decades in their relationships with the neighbours: "The key principles of the revised ENP are differentiation amongst partner countries, flexibility, joint ownership, greater involvement of the EU Member States, and shared responsibility". To add even further, it is clearly stated that the ENP is not offering the prospects of admission to the partner countries: "Through the ENP, the EU offers partner countries potential greater access to the EU's market and regulatory framework, standards and internal agencies and programmes". If enlargement policy involved the adoption of the full acquis communautaire by the candidate countries, the expectations regarding the countries forming the "Neighbourhood" are much lower (Bruns, Happ, Zichner 2016, 3). However, this does not mean that the expectations of the partner countries from their relationship with the European Union are also low. The closer it gets Europe in relationship with its neighbours, the greater is getting the power of attraction towards it. The development of civil society in the "Neighbourhood" is stimulated by the financial aid offered by the EU and the opportunities to be involved in a whole spectrum of positive interactions with European citizens, local governments, EU officials, NGOs, and companies, to name just a few number of actors having stakes in cross-border cooperation. The civil society of the neighbouring countries becomes the pro-European agent wanting democratic political change that would mirror the European political realities. Not to mention the fact that this civil society is becoming 
the best advocate for association agreements between its country and the EU. The image of "Euromaidan" movement is illustrative. What was happening in Ukraine had happened in Central Europe in 1989. The same forces driving Poland, Hungary, and Czechoslovakia towards the Big Bang enlargement of 2004 seemed to work in Kiev.

The policy provides support for the countries from the neighbourhood through a financial instrument, the European Neighbourhood Instrument (ENI) "with over E U R 15 billion for 2014-2020". It replaced the former financial instrument of the ENP, called European Neighbourhood and Partnership Instrument which had a budget of over EUR 11 billion for the period 2007-2013. Moreover, the ENPI and ENI have been designed to include previous financial instruments of the European Union regarding the neighbourhood, such as the CBC programmes (which became ENPI CBC and currently ENI CBC). The new financial instruments were building on INTERREG IIIA/TACIS CBC 2004-2006 Neighbourhood programmes (Marin, 2016: 124). While the numbers are not impressive

When it was launched, the European Neighbourhood Policy had as objectives "avoiding the emergence of new dividing lines between the enlarged EU and its neighbours and instead strengthening the prosperity, stability and security of all. It is based on the values of democracy, rule of law and respect of human rights". Following the Arab Spring and the crisis in Ukraine, the main focus is on "stabilisation of the region, in political, economic, and security related terms" (the quotes are from the website: https:/ / ec.europa.eu/neighbourhood-enlargement/neighbourhood/overview_en). The geopolitical aspects of the European Neighbourhood Policy are easily identifiable even though they may never be acknowledged by the EU officials. Clearly, the EU is not a classical empire, a fact demonstrated by the way it manages its borders. A classical empire would employ either a policy of conquest directed towards the weaker neighbours, using force to obtain submission or imposing client states, or a policy of defence, building walls to keep "barbarians" out. A symbolical empire, or a soft empire, will rather try to influence the behaviour of the neighbours so that they might begin sharing its values, principles, and norms. Unfortunately, the events taking place in the last years in Ukraine have demonstrated that while the European Union has built a new frontier policy, the ENP, to manage the relations with its Southern and Eastern neighbours, a clash with Moscow has become 
increasingly unavoidable. The Eastern Partnership, an initiative of Sweden and Poland, is for Russia a recollection of other Western policies that ended in weakening its geopolitical position (for instance the NATO Partnership). Russia seems unable to differentiate the European Union's approach from that of a Great Power seeking territorial aggrandizement. Russia still perceives the former Soviet states, and especially Ukraine, Belarus and Moldova as part of its geopolitical hinterland.

\section{THE EURASIAN GEOPOLITICAL SCHOOL OF RUSSIA}

Even though after 1991 there were several geopolitical trends supporting the integration of Russia in the Euro-Atlantic space (an example would be the ideas of Dmitri Trenin ${ }^{1}$ ), stating that Russia no longer has the same imperial vocation it use to have during the Soviet past, they were rejected by most other trends. The dominant school came to be Eurasianism, a geopolitical school developed by the Russian geo-politician Alexandr Dugin, also the leader of the Eurasia Movement. Dugin is influenced by the great yet controversial German philosopher Martin Heidegger, reputed for - among many things - his anti-technological views. Even though Dugin is maintaining, in a liberal manner, that technology is a form of progress, he also states, in Heideggerian manner, that Russia should abandon the internet, alongside some contemporary sciences like physics and chemistry (qz.com). In fact, Dugin is the supporter of a geopolitical land geo-cultural antithesis already explored for more than a century by his geopolitical predecessors: the fight between, on the one hand, the "world of the sea" (thallasocratia, which he names it Atlantis) - a decadent civilization of commerce and consumption, supporting liberal ideals, and "the world of the land" (tellurocracy) - based on presumably moral, conservative, patriarchal, autocratic

${ }^{1}$ The author of a book whose title speaks for itself: The End of Eurasia: Russia on the Border Between Geopolitics and Globalization, Carnegie Endowment for International Peace, Washington, D.C., 2001. 
ideals, closed to the traditional values. Obviously, Russia is the historical exponent of the latter.

Dugin, author of several books of geopolitics (best known for Foundations of Geopolitics), philosophy or metaphysics, promoted the idea of Russia's Eurasian expansionism. He consistently inspired himself from the works of the classical German geopolitical school and of the Anglo-Saxon school of geostrategy. His research design resembles that of Karl Haushofer. Here is a synthesis of his ideas:

First of all, Dugin outlines the future directions of action for Russia, these being:

- Inside, Russia should establish, based on a reform, a multi-ethnic and multi-religious state, spreading Panslavism and Panorthodoxism;

- Outside, Russia must counterbalance the Anglo-Saxon maritime powers promoting alliances with Germany and Japan;

The Russian geopolitician supports three special projects drawn accordingly to Russia's geopolitical aims:

$>$ Pan-European: aiming to the establishment of a European empire built aroung Germany and it's concept of Mitteleuropa $(!)$

> Pan-Islamic: a Muslim empire in Central Asia built around Iran

$>$ Pan-Asiatic: an empire in the Pacific region, organized around Japan.

Russia will never be a part of these empires since it is already a great empire and it has the vocation of dominating the others, according to Dugin.

Dugin's geopolitical projects are much more related to the geopolitical imagination than to possible realities. There are many factors that prevent the materialization of the Eurasian project of Dugin, however seductive would be for the contemporary Russian political elite.

Even the Russian geopolitical admits that the Eurasian scenario is not certain, since it is not assumed by the entire Russian political and intellectual elite. Russia is in fact the prisoner of a "protracted geopolitical crisis", according to Dugin. He emphasises that "the most dispassionate and impartial analysis of Russia's geopolitics shows that today's position is a pathology, a deviation from its natural, undeniable historical trajectory" (Dugin 2015, 96). 
Among the harsh conclusions that Dugin is making in his geopolitical manifesto of 2015 the following one cautions us: "Therefore, geopolitically, it is unfounded and empty to hope that Russia will be able to preserve itself in the reduced and regional form in which it now exists, after repudiating mobilization, a new round of expansion, and any participation in world-historical processes on behalf of the civilization of Land (expressed today in the principle of multipolarity" (Dugin 2015, 97). Dugin's work remains critical even towards the administration which he clearly influenced so far: Putin Administration.

\section{FROM THE EURASIAN THEORY TO THE GEOPOLITICAL PRACTISE OF PUTIN ADMINISTRATION}

It is probably an exaggeration to state that the Eurasian project of Dugin dominates the foreign and security policy agenda of the Russian Federation, though there are several aspects seeming to confirm the influence of Dugin's ideas on Putin Administration, among which the Eurasian Union and the occupation of Crimea. Even the important review of international relations Foreign A ffairs headlined in March 2014: "Putin's Brain : A lexander Dugin and the Philosophy Behind Putin's Invasion of Crimea". In fact, in 2015 the US and Canada put him on the list of sanctioned individuals as a result of his involvement in the Ukrainian crisis.

However, it would be very hard to suggest that the Kremlin's leaders do not know very well the facts: Russia is in a deep demographic decline and its economic growth, no matter how spectacular it was so far, it brings it to the 10th place worldwide, far behind some geopolitical actors of global importance such as the EU, US and China.

Currently, it seems evident that geopolitics is used as an instrument of power for Vladimir Putin's Russia, but more than that, as an instrument of propaganda, enjoying success among the Russian population, and some right-wing elements from Europe and the US. However, in the light of Russian history, pragmatism is the dominant word. Russia will always seek to obtain a much more important place at the negotiation table regarding global politics, but this place will much 
depend on the international recognition and in the lack of reaction by the other power centres towards the major claims of Russia. Russia will not risk a world war, the nuclear deadlock remaining constant, even though an author such as Alexander Dugin keeps preaching a "war of civilizations" with a clear finality. Russia's objective remains to accumulate more international prestige and in its geopolitical imaginary this cannot be obtained unless it will be treated as equal partner by the United States of America.

Regarding the European Union and its "neighbourhood policy" Russia seems to be unable to judge the EU as a new type of political entity that even defies the habits of a traditional Great Power. Even though the EU is lacking a common army that could pose a threat to Russian borders, the Kremlin is very reactive against any European enlargement towards its "Near Abroad", probably because it makes no clear difference between the EU and NATO, the US, or the "West". The old Russian school of geopolitical thinking is still involved in the political establishment. This probably explains why Russia implemented an alternative plan in Ukraine after the demise of Viktor Janukovic, namely the annexation of Crimea and the destabilization of the Donetsk region.

Ukraine was the second largest Soviet republic in terms of population. The Russian geopolitical imagination is still haunted by the loss of an empire that rivalled only with the United States. The reaction of Moscow to the presumed loss of Ukraine reminded also that in 2008 Georgia wanted to join NATO.

\section{CONCLUSIONS}

The European Union and Russia seem to be on a collision course in geopolitical and geo-economic terms. It is a clash between a soft power and a hard power. However, both actors are not currently in their best seats. They are both facing a very radicalized environment, prone to revolutionary change. This is especially true for the countries of North Africa and the Middle East, but the Euromaidan showed that this potential exists also for the countries of Eastern Europe. Geopolitical approaches may come to be only illusions of political elites that are losing the control over their civil societies. The ENP may not stop citizens' desire 
to get closer to an area of stability and prosperity such as the European Union. Classical geopolitical approaches may fail to prevent Eastern civil societies to live the dream of uniting with Europe as an exponent of Western civilization.

\section{REFERENCES}

- Barbashin, Anton and Thoburn, Hannah, "Putin's Brain: Alexander Dugin and the Philosophy Behind Putin's Invasion of Crimea". Foreign Affairs, March 2014.

- $\quad$ Batt, Judy; Lynch, Dov et al., "Partenaires et voisins: une PESC pour une Europe élargie", Cahiers de Chaillot, nr. 64, EU-ISS, September 2003.

- $\quad$ Bruns, Bettina; Happ, Dorit; Zichner, Helga (eds.), European N eighborhood Policy: Geopolitics between integration and security, London: Palgrave Macmillan, 2016.

- $\quad$ Cohen, Saul B., Geopolitics: The Geography of International Relations, 3rd edition, Lanham: Rowman\&Littlefield, 2015.

- Dugin, Alexander, Last War of the World Island: The Geopolitics of Contemporary Russia, London: Arktos, 2015.

- $\quad$ EEAS, „European Security Strategy - A Secure Europe in a Better World", Brussels, 12 December $2003 . \quad$ Website:

https://europa.eu/globalstrategy/en/european-security-strategy-secureeurope-better-world

- $\quad$ European Commission, “Wider Europe's Neighbourhood: proposed new framework for relations with the EU's Eastern and Southern Neighbours", Brussels, 11 ${ }^{\text {th }}$ March 2003. Internet: http:/ / europa.eu/rapid/press-release_IP-03358_en.htm

- European Commission: https://ec.europa.eu/neighbourhoodenlargement/neighbourhood/overview_en

- European Council, "A Secure Europe in a Better World: European Security Strategy", Brussels, 12 December 2003. Internet: http:/ / www.envirosecurity.org/ges/ESS12Dec2003.pdf

- $\quad$ Gowan, Peter, "The EU and Eastern Europe: Diversity without Unity?", in Mary Farrell, Stefano Fella, Michael Newman, European Integration in the 21st Century. U nity in Diversity?, SAGE Publications, Londra, Thousand Oaks, New Delhi, 2002, pp. 29-30. 
- $\quad$ Grabbe, Heather, "The Sharp Edges of Europe: Security Implications of Extending EU Border Policies Eastwards", EU-ISS O ccasional Paper 13, Paris, March 2000.

- $\quad$ Grudzinski, Przemyslaw, Ham, Peter van, A Critical A pproach to European Security: Identity and Institutions, London and New York: Pinter, 1999.

- $\quad$ Kaplan, Robert D., The Revenge of Geography: W hat the map tells us about the coming conflicts and the battle against fate, New York: Random House, 2012.

- Kelly, Phill, Classical Geopolitics: A New Analytical Model, Stanford: Stanford University Press, 2016.

- Marin, Anais, "Of barriers, breaches and bridges: cross-border ecoturism and the prospect of horizontal governance acting as bridge in the Belarus-EU Neighborhood Relations", in Liikanen, I., Scott, J.W., Sotkasiira, T., The EU's Eastern N eighborhood: M igration, Borders and Regional Stability, London and New York: Routledge, 2016, pp.115-134.

- Qz.com, “The philosopher known as "Putin's brain" is a big fan of Trump", https://qz.com/871975/aleksandr-dugin-putins-favorite-philosopheris-a-big-fan-of-donald-trump/

- Toal, Gerard (Ó Tuathail, Gearóid in Irish), Critical Geopolitics: The Politics of W ritting Global Space, London: Routledge, 1996.

- $\quad$ Trenin, Dmitri, The End of Eurasia: Russia on the Border Between Geopolitics and Globalization, , Washington: Carnegie Endowment for International Peace, 2001.

- Tunander, Ola, "Post-Cold War Europe: Synthesis of a bipolar friend-foe structure and a hierarchic Cosmos-Chaos Structure?", in Tunander, O., Baev, P., Einagel, V. I. (eds.), Geopolitics in Post-W all Europe: Security, Territory and Identity, Oslo: SAGE Publications, 1997.

- Wæver, Ole, “After Neo-Medievalism: Imperial Metaphors for European Security", in Burgess, Peter (ed.), Cultural Politics and Political Culture in Postmodern Europe, Amsterdam, Atlanta: Rodopi, 1997, pp. 321-366.

- Wæver, Ole, “Imperial Metaphors: Emerging European Analogies to PreNation-State Imperial Systems", in Tunander, O., Baev, P., Einagel, V. I. (eds.), Geopolitics in Post-Wall Europe: Security, Territory and Identity, Oslo: SAGE Publications, 1997, pp. 66-72. 